\title{
Morphological diversity of microstructures occurring in selected recent bivalve shells and their ecological implications
}

\author{
Krzysztof Roman Brom*, Krzysztof Szopa \\ Faculty of Earth Sciences, University of Silesia, ul. Będzińska 60, 41-200 Sosnowiec, Poland \\ *Correspondence: kbrom@us.edu.pl
}

Received: $17^{\text {th }}$ August, 2016

Accepted: $17^{\text {th }}$ November, 2016

\begin{abstract}
Environmental adaptation of molluscs during evolution has led to form biomineral exoskeleton - shell. The main compound of their shells is calcium carbonate, which is represented by calcite and/or aragonite. The mineral part, together with the biopolymer matrix, forms many types of microstructures, which are differ in texture. Different types of internal shell microstructures are characteristic for some bivalve groups. Studied bivalve species (freshwater species - duck mussel (Anodonta anatina Linnaeus, 1758) and marine species common cockle (Cerastoderma edule Linnaeus, 1758), lyrate Asiatic hard clam (Meretrix lyrata Sowerby II, 1851) and blue mussel (Mytilus edulis Linnaeus, 1758)) from different locations and environmental conditions, show that the internal shell microstructure with the shell morphology and thickness have critical impact to the ability to survive in changing environment and also to the probability of surviving predator attack. Moreover, more detailed studies on molluscan structures might be responsible for create mechanically resistant nanomaterials.
\end{abstract}

Key words: shell, calcium carbonate, microstructures, biomineral, anti-predator adaptations

\section{Introduction}

Biomineral exoskeletons frequently exhibit unique hierarchical internal structures, which increase mechanical strength of them. Organisms which evolve in the environment, where they are constantly exposed to unfavourable environmental factors, generally use them as a protecting armor or to strengthen their bodies. Examples of such organisms are shelly faunas (like Mollusca), which possess shells made mainly of calcium carbonate (Vincent et al. 2006; Futuyma 2008; Barthelat et al. 2009; Brom et al. 2015).

Early molluscs species, probably in order to reduce pressure from predators, adopted a strategy of armor and formed exoskeleton during the "Cambrian explosion" due to the necessity of mechanical protection of soft tissues with impaired ability to regenerate (Pokryszko 2009; Jackson et al. 2010; Vendrasco et al. 2010). Further, pressure from shell-crushing and shell-drilling predators results in origin of appropriate shell microstructures, in order to increase mechanical strength of shell (Taylor and Layman 1972; Ragaini and Di Celma 2009; Kosnik et al. 2011).

Bivalve shell is the product of mantle (pallium) and it is composed mainly of calcium carbonate (in the form of calcite and/or aragonite), which constitutes at least $95 \%$ of its weight, and the biopolymers forming organic matrix (Dyduch-Falniowska and Piechocki 1993; Barthelat et al. 2009; Piechocki 2009; Katti et al. 2010; Meyers et al. 
2011). It divides into three main layers. The most outer layer, called periostracum, is made mostly of complex protein conchiolin. Next layer - middle (mesostracum) is primarily composed of calcium carbonate crystals. Third, the inner layer (hypostracum) is built by $\mathrm{Ca}$ rich carbonate plates. The first two layers are formed by the edge of the mantle, and the last one by the entire surface of epithelial tissue (Urbański 1989; Dyduch-Falinowski and Piechocki 1993; Jura 2005; de Paula and Silveira 2009; Piechocki 2009). Morphology, structure and other adaptations of bivalve molluscs have critical impact on ability to survive in constantly changing environment and also to increase the probability of surviving predator attack (Vermeij 1977, 1987).

The main aim of this paper is to describe the morphological diversity of microstructures present in the studied shells of some selected recent bivalve species. Additionally, the authors attempt answer what is the main function of each identified structures in contexts of anti-predator adaptations.

\section{Materials and methods}

The following species of bivalve: 1) duck mussel (Anodonta anatina Linnaeus, 1758), 2) common cockle (Cerastoderma edule Linnaeus, 1758), 3) lyrate Asiatic hard clam (Meretrix lyrata Sowerby II, 1851) and 4) blue mussel (Mytilus edulis Linnaeus, 1758), were collected from different locations. All the studied shells were washed and measured (Table 1; Fig. 1). Afterwards, every shell sample (one whole shell for each investigated species) was fractured in order to show the microstructural details. Fractures were made parallel and perpendicular to the umbo-ventral margin axis in the central part of the valves. Both left and the right valves were investigated.

Scanning electron microscope observation, including BSE images and EDS analyses were obtained by using a Philips XL30 ESEM/TMP equipped with EDS (EDAX type Sapphire) detector at the Faculty of Earth Sciences, University of Silesia.

Tab.1. Selected macroscopic characteristics of the investigated bivalve including provenance area.

\begin{tabular}{|c|c|c|c|}
\hline Bivalve species & $\begin{array}{c}\text { Sample } \\
\text { collecting place }\end{array}$ & $\begin{array}{c}\text { Shell length measured from } \\
\text { umbo to ventral margin } \\
{[\mathrm{mm}]}\end{array}$ & $\begin{array}{l}\text { Shell height measured from } \\
\text { anterior (foot) end to posterior } \\
\text { (siphon) end }[\mathrm{mm}]\end{array}$ \\
\hline $\begin{array}{c}\text { Duck mussel } \\
\text { (Anodonta anatina) }\end{array}$ & $\begin{array}{l}\text { Vistula river } \\
\text { estuary }\end{array}$ & 79 & 105 \\
\hline $\begin{array}{c}\text { Common cockle } \\
\text { (Cerastoderma edule) }\end{array}$ & Baltic Sea & 49 & 48 \\
\hline $\begin{array}{l}\text { Lyrate Asiatic hard clam } \\
\text { (Meretrix lyrata })\end{array}$ & $\begin{array}{c}\text { South West } \\
\text { Pacific Ocean }\end{array}$ & 38 & 43 \\
\hline $\begin{array}{c}\text { Blue mussel } \\
\text { (Mytilus edulis) }\end{array}$ & Irish Sea & 52 & 34 \\
\hline
\end{tabular}




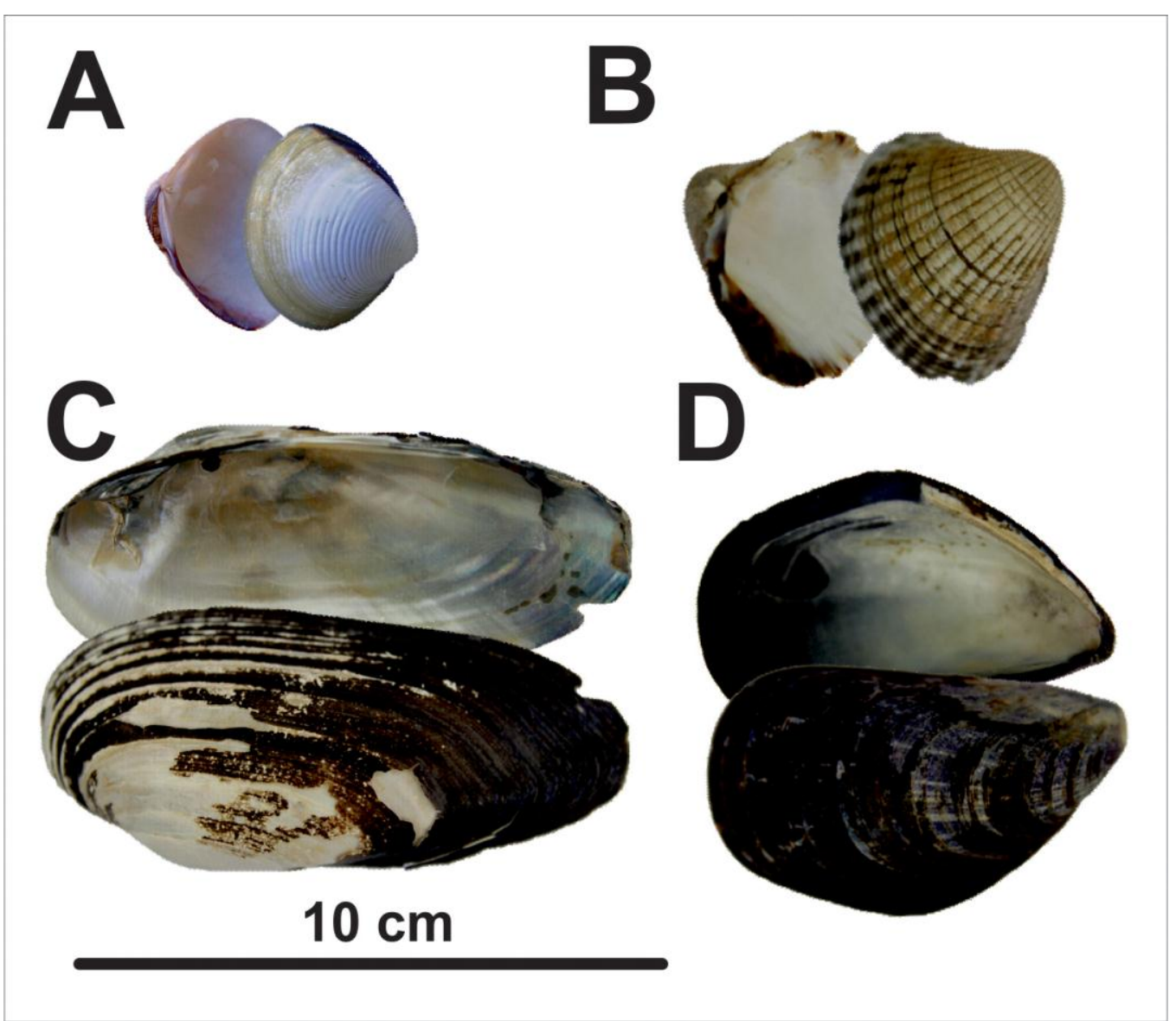

Fig.1. General morphology of studied bivalves: A) lyrate Asiatic hard clam (Meretrix lyrata), B) common cockle (Cerastoderma edule), C) duck mussel (Anodonta anatina) and D) blue mussel (Mytilus edulis). Scale bar equal to $10 \mathrm{~cm}$.

\section{Results}

\section{Microstructures}

Each of the examined bivalve species is characterized by the presence of different types of microstructures. They were visible in the second (mesostracum) and third (hypostracum) layer. In all studied cases, the shell structures are homogenous in chemical composition, but exhibit various structures. Only in one case (freshwater $A$. anatina), the well visible presence of organic matrix is expressed by biopolymer content in obtained BSE images. All structures were identified according to Grégoire (1972) and also to Carter et al. (2013).

\section{Duck mussel (Anodonta anatina)}

The first layer - periostracum was especially well visible in A. anatina. It is part, conchioline is also forming the organic matrix of the shell within which calcium carbonate is deposited (Fig. 2a). Under the first layer, another duplex structure was found. One part is represented by long carbonate crystal, which forms prisms. The crystals are 0.1 to $0.8 \mathrm{~mm}$ long and 50-60 $\mu \mathrm{m}$ wide (Fig. 2). Investigated prism from $A$. anatina shell have a polygonal joint pattern both in the contact zone with periostracum and the most internal layer socalled nacreous layer, columnar nacre type (Fig. 2b - lower part). The last part is built by numerous $(\leq 1 \mu \mathrm{m})$ thin carbonate plates. 


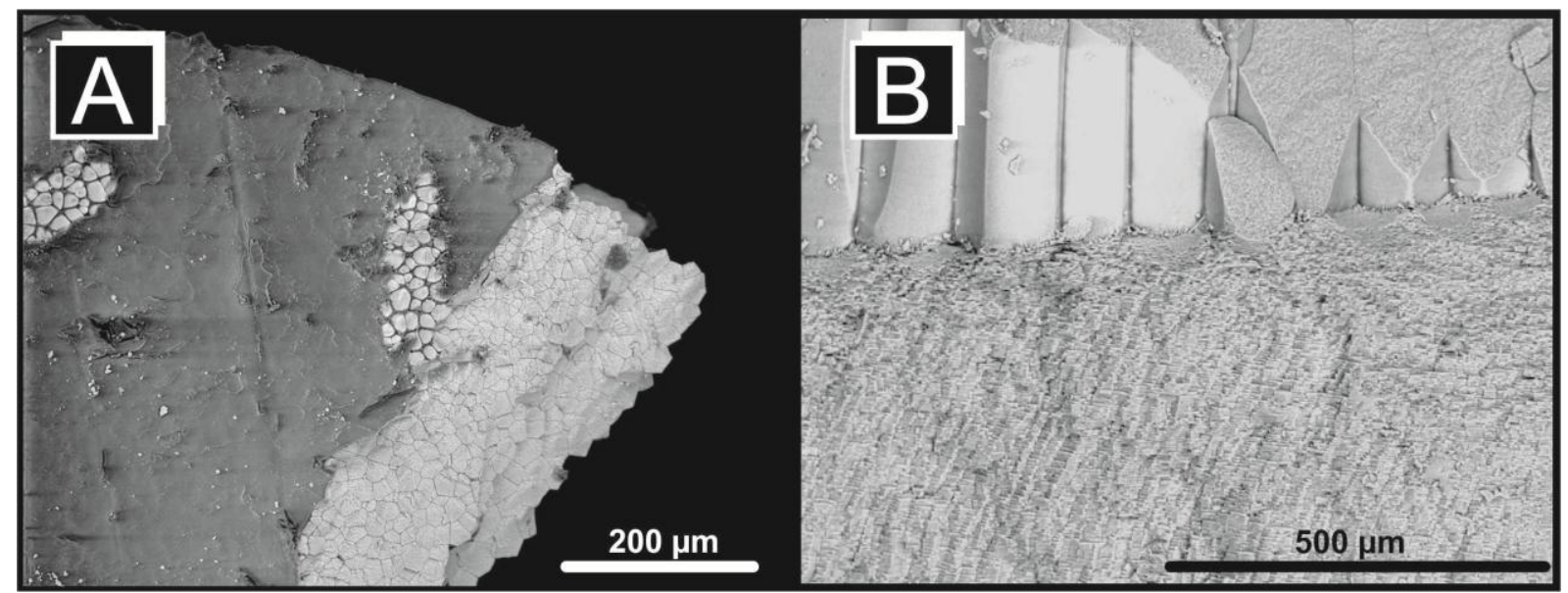

Fig.2. BSE images of microstructures in A. anatina (A-B). A. anatina is characterized by two, well visible layers. Outer part of the shell is cover by periostracum layer, under it the bases of prismatic structure crystals are present (A). Side view of prismatic structure and Ca-rich carbonaceous plates of "columnar nacre" hypostracum are also visible $(\mathrm{B})$.

\section{Common cockle (Cerastoderma edule)}

C. edule has a shell composed of a homogeneous outer layer (Fig. 3a), while the lower layer is formed by fiber-like carbonate crystals (Fig. 3b). This part show massive fabric comprising closely packed fiber-like calcium carbonate crystals less than $1 \mu \mathrm{m}$ in size, without any pores visible both macroscopically and microscopically.

\section{Lyrate Asiatic hard clam (Meretrix lyrata)}

Duplex structure was noticed in M. lyrata. The upper part is built by layered part (foliated structure), where a single carbonate layer may reach up to $<<5 \mu \mathrm{m}$ in thickness (Fig. 4a). Crossed lamellar structure forms the lower part of the shell and is characterized by occurrence of large number of the thicker first order lamellae (from a few up to $10 \mu \mathrm{m}$ ) than the previously ones (Fig. 4b).

\section{Blue mussel (Mytilus edulis)}

The inner layer of M. edulis shell has two well visible microstructers. The most upper layer is composed by platy carbonate crystal (foliated structure). The crystal thickness reaches up tens of micrometers (Fig. 5a). Sporadically, small pores with c.a. 1-2 $\mu \mathrm{m}$ in diameter are noted. Below the first layer a prismatic structure is presented (Fig. 5b). It is composed of well elongated carbonate crystals. They are $>200 \mu \mathrm{m}$ long and show sharp fiber-like forms with the aspect ratios <400:1. This structure is referred to fibrous prismatic structure, not the same as in case of simple prismatic structure in A. anatina (see below).

\section{Discussion}

Mechanical strength of the animal exoskeleton, including molluscs shells, determines their ability to survive under changing physicochemical and biological environmental conditions. According to many authors, the origin of shells in the Conchifera was probably due to the necessity of mechanical protection of body from durophagous predators. Bivalve molluscs by developing exoskeleton (shell) established a suitable protection against predators (eg. Barthelat al. 2009; Piechocki 2009).

Calcium carbonate builds several types of shell structures, differing in the spatial orientation of crystals in the shell-made layers. 


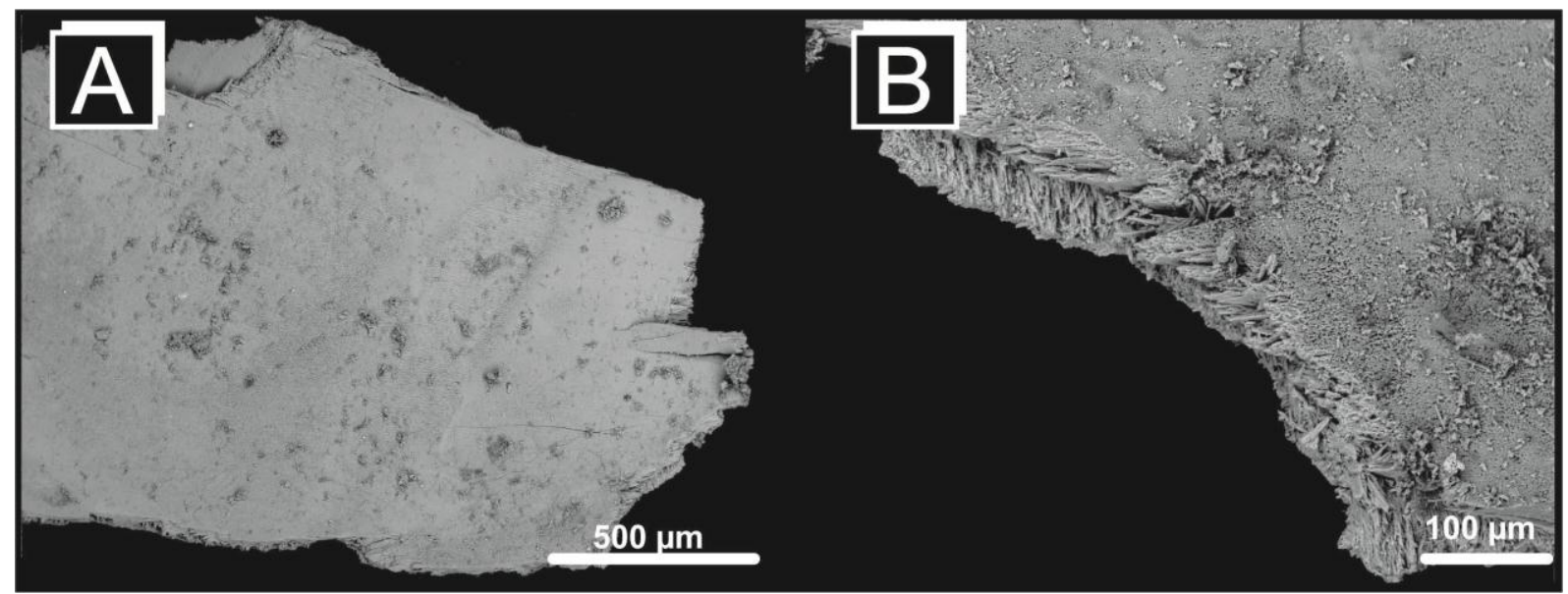

Fig.3. BSE images of microstructures in C. edule (A-B). C. edule has the shell composed of homogeneous outer layer (A), while the lower part is formed by fiber-like carbonate crystals (B).

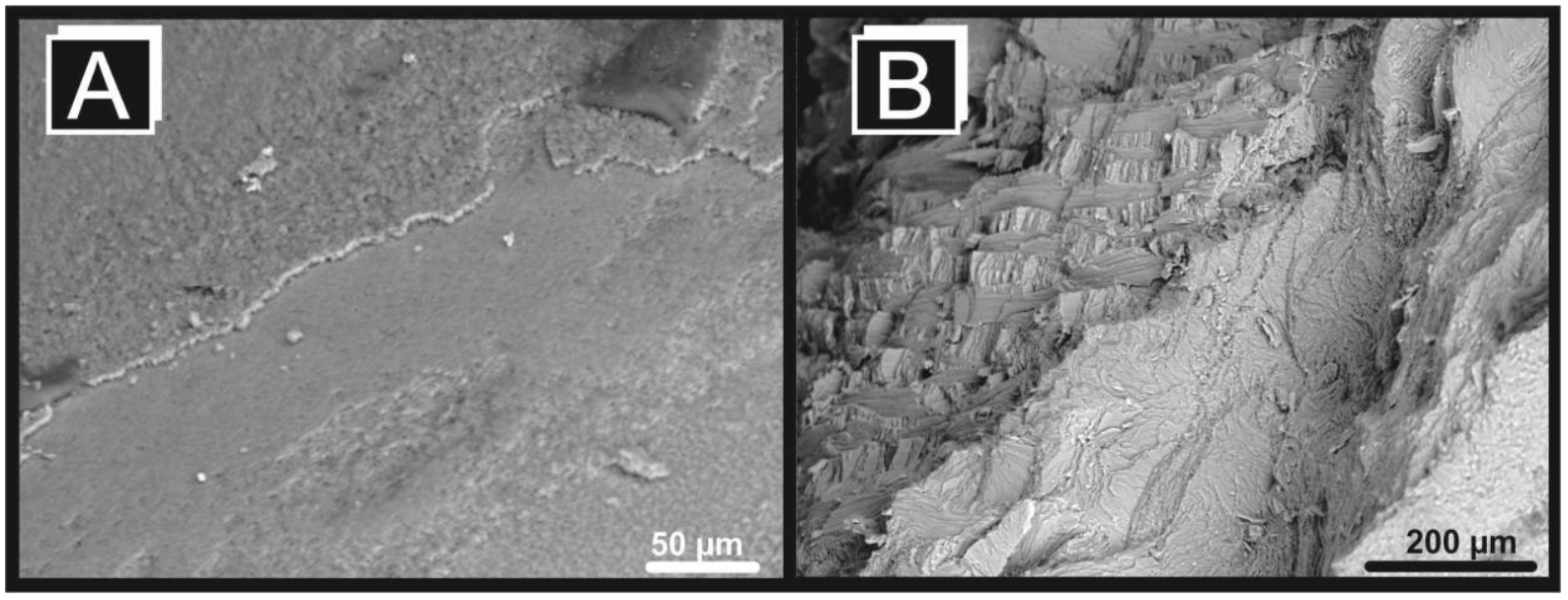

Fig.4. BSE images of microstructures in M. lyrata (A-B). M. lyrata shell has shown duplex structure. The first part is formed by homogenous thin carbonate layer (A). Crossed lamellar structure forms the lower part of the shell (B).

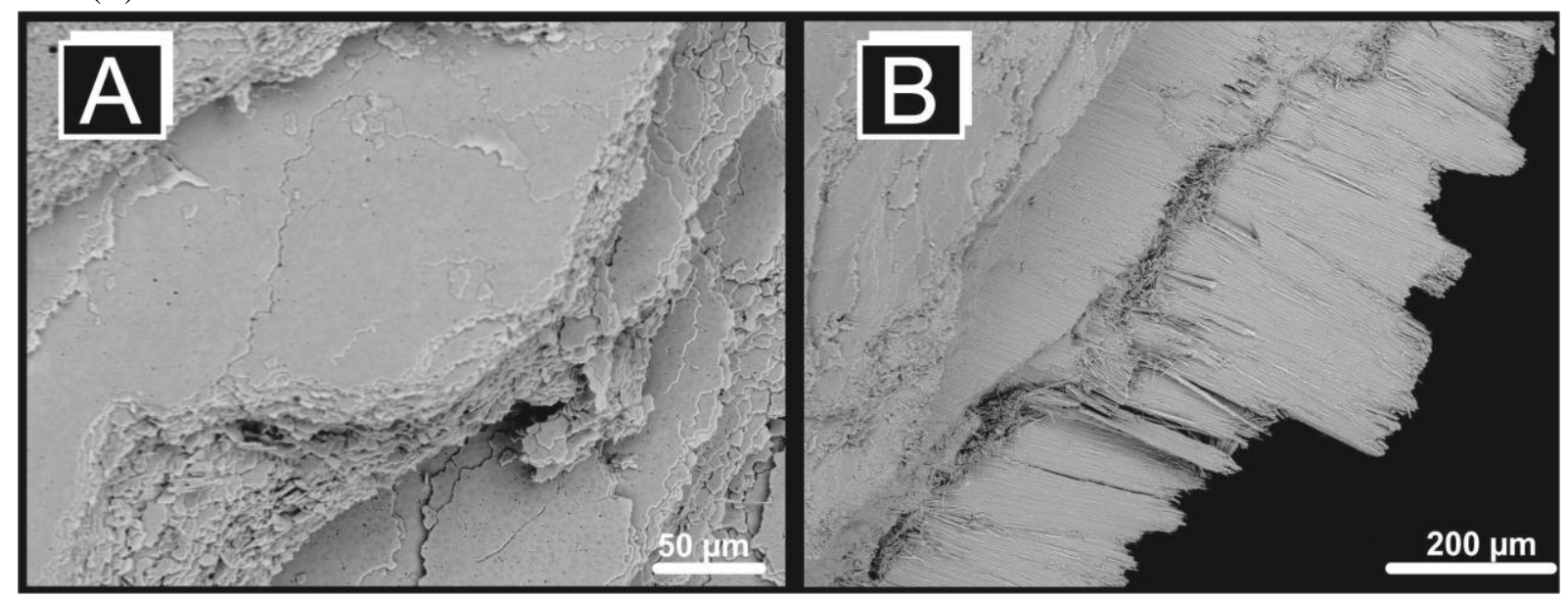

Fig.5. BSE images of microstructures in M. edulis (A-B). The most upper layer is composed by platy carbonate crystal (A), below the first layer prismatic structure is presented (B).

This phenomenon leads to difference in mechanical properties of the shell within the various species groups of Mollusca and their resistance to crushing and drilling (Chateigner et al. 2000; Barthelat et al. 2009; Katti et al. 2010). The main layers affecting to the

\section{OPEN}


mechanical strength are mesostracum and in lesser extent hypostracum. Periostracum layer has the lowest participation in mechanical protection (Harper and Skelton 1993; Ishikawa and Kase 2007). Mesostracum exhibits various crystals orientations in different bivalve species as was shown in this paper.

Differences in the structure of shells are most likely related to the necessity of stronger or lesser mechanical protection of animals and it is also connected with various anti-predator adaptations.

Species like A. anatina occur in the some rives of Poland, like Vistula and Oder and lakes, where are exposed to predatory fishes. For this reason, A. anatina buried in the mud, makes itself much less accessible to predators. Therefore, A. anatina as the main anti-predator adaptation adopted infaunal benthic mode of life (Lewandowski 2004), not strengthening their shell by more durable structures. Although, A. anatina exhibit well visible "columnar nacre" hypostracum layer, which is mostly responsible for increasing the flexibility of shells (Barthelat et al. 2009; Katti et al. 2010; Salinas and Kisailus 2013; Brom et al. 2015). The main function of structures occurring in A. anatina is probably dissipating the hydrostatic pressure forces. Additionally, A. anatina exhibit relatively high level of fertility (Lewandowski 2004).

Species like $C$. edule which occur in the Baltic Sea are not exposed to the increased pressure from predators (Hällfors et al. 1981). C. edule also exhibit relatively high level of fertility, making this species one of the most abundant of molluscs in tidal flats in the bays and estuaries of Europe (Poorten and Gofas 2014). Probably that is the reason why even high level of pressure from shelly fauna predators would not lead to the extinction of this species. In this case mechanical strength of its shell also plays a secondary role.

Currently crossed-lammelar structure is considered as one of the most crushingresistant structures which occur in invertebrates (eg. Sarikaya et al. 1989; Baohua and Gao 2004; Barthelat al. 2009; Chen et al. 2008; Katti et al. 2010). This is probably the reason why this structure is present in molluscs living in environments where there are constantly exposed to the presence of predators, in basins where the trophic webs are most complex. $M$. lyrata is example of species that lives in warm seas of the Pacific and Atlantic Oceans in epipelagic zones, where the number of potential predators is the highest (Piechocki 2009; Huber 2015). Therefore, these species had to form sufficiently tough structure to protect them from crush. The shell of $M$. lyrata also is cover by homogenous structure without pores. Additionally, to avoid attacks by predators it buries in the sea sand or mud, similar like A. anatina, so it also belongs to the infaunal benthos animal ecological group (Bernard et al. 1993; Huber 2015). Burrowing in the sea surface and possess durable crossed lamellar structure allows this species to survive in an unfavorable environment. Durable crossed lamellar structure also occur e.g. in Pecten maximus (Linnaeus, 1758). Scallops belong to the socalled free lying bivalve molluscs, therefore, they are the most exposed for potential attack (Harper and Skelton 1993; Piechocki 2009; Brom et al. 2016).

The bivalve $M$. edulis represent epifaunal mode of life. It attached to rocks and other hard substrates by strong and elastic threadlike structures called byssal threads, secreted by byssal glands (Thompson 1979). For this reason, it belongs to byssally attached bivalve ecological category (Harper and Skelton 1993). Byssal thread production is also considered as anti-predator adaptations (Cheung et al. 2006; Caro et al. 2008; López et al. 2010), bivalves like Asian green mussel (Perna viridis, Mytilinae) and Brachidontes variabilis (also Mytilinae) increased byssal thread production, as well as the thicker and longer byssal threads when they were exposed to shell-crushing crabs. By increasing the strength of byssal 
attachment as a defensive trait, the chance of being dislodged and consumed by crabs is reduced (Cheung et al. 2006). Prismatic structure occurring in M. edulis is not its main adaptation aimed to increasing the chances of survival in case of durophagous attack. It is also not quite as durable as the other structures (Zuschin and Stanton 2001).

\section{Conclusions}

Structures which forming bivalve shells exhibit major influence their mechanical strength (eg. Barthelat al. 2009; Harper and Skelton 1993). This strength is critical to the survival of predator attacks and the dissipation of hydrostatic pressure. However, not only shellmade hierarchical structures can be classified as anti-predator adaptations. Additionally, mode of life (eg. infaunal or epifaunal), the level of fertility, occupied environment, ability to active escape and ecological category (like bysally attached bivalves) increase the chance of survival under the unfavorable environmental conditions. Further, there are also other (not described here) defense and survival strategies, like shell thickness, acquired toxicity, enhanced shell ornamentation, camouflage, cemented or borer bivalve mode of life (described further in Harper and Skelton 1993).

Molluscs evolved also by optimized their exoskeleton and by acquiring number of adaptations that currently are carefully studied by bionic engineering scientists. This kind of research is highly promising and endeavor to produce nanomaterials with similar attributes as mollusc shells (eg. Barthelat et al. 2009).

\section{Acknowledgement}

The authors are greatly indebted to Dr Łukasz Chajec (University of Silesia) and anonymous reviewer for their constructive comments and helpful suggestions. The project has been financed from the funds of the
Leading National Research Centre (KNOW) received by the Centre for Polar Studies for the period 2014-2018.

\section{References}

Baohua J., Gao H. (2004) Mechanical properties of nanostructure of biological materials. Journal of the Mechanics and Physics of Solids 52, 1963-1990.

Barthelat F., Rim J.E., Espinosa H.D. (2009) A Review on the Structure and Mechanical Properties of Mollusk Shells. Perspectives on Synthetic Biomimetic Materials. Applied Scanning Probe Methods XIII, Biomimetics and Industrial Applications 17-44.

Bernard F.R., Cai Y.Y., Morton B. (1993) Catalogue of the living marine bivalve molluscs of China. Hong Kong University Press.

Brom K.R., Salamon M.A., Skreczko S. (2015) Właściwości strukturalne muszli mięczaków jako inspiracja inżynierii bionicznej. Kosmos 64(2), 365-375.

Brom K.R., Szopa K., Krzykawski T., Brachaniec T., Salamon M.A. (2016) Antipredator adaptations in a great scallop (Pecten maximus) - a palaeontological perspective. Geoscience Records 1(1-2), 16-20, DOI:10.1515/georec-2015-0002

Caro A.U., Escobar J., Bozinovic F., Navarrete S.A., Castilla J.C. (2008) Phenotypic variability in byssus thread production of intertidal mussels induced by predators with different feeding strategies. Marine Ecology Progress Series 372, 127-134.

Carter J.G., Bandel K., de Buffrénil V., Carlson S., Castanet J., Dalingwater J., Francillon-Vieillot H., Géraudie J., Meunier F.J., Mutvei H., de Ricqlès A., Sire J.Y., Smith A., Wendt J., Williams A., Zylberberg L. (2013) Glossary of Skeletal Biomineralization. [In:] Skeletal Biomineralization: Patterns, Processes and Evolutionary Trends (ed. J.G. Carter). 
American Geophysical Union (Short Courses in Geology Series), Washington, DC, 337-352.

Chateigner D., Hedegaard C., Wenk H.R. (2000) Mollusc shell microstructures and crystallographic textures. Journal of Structural Geology 22 (11-12), 1723-1735.

Chen P.Y., Lin A.Y.M., Lin Y.S., Seki Y., Stokes A.G., Peyras J., Olevsky E.A., Meyers M.A., McKittrick J. (2008) Structure and mechanical properties of selected biological materials. Journal of the Mechanical Behavior of Biomedical Materials 1, 208-226.

Cheung S.G., Luk K.C., Shin P.K.S. (2006) Predator-Labeling Effect on Byssus Production in Marine Mussels Perna viridis (L.) and Brachidontes variabilis (Krauss). Journal of Chemical Ecology 32(7), 1501-1512.

Dyduch-Falniowska A., Piechocki A. (1993) Mięczaki (Mollusca) - Małże (Bivalvia). Wydawnictwo Naukowe PWN.

Futuyma D.J. (2008) Koewolucja: rozwijanie interakcji międzygatunkowych. [In:] Ewolucja (ed. D.J. Futuyma). Wydawnictwa Uniwersytetu Warszawskiego, Warszawa, 437-456.

Grégoire C. (1972) Structure of the molluscan shell. Chemical Zoology 2, 45-102.

Harper E.M., Skelton P.W. (1993) The Mesozoic marine revolution and epifaunal bivalves. Scripta Geologica, Special Issue 2, 127-153.

Hällfors G., Niemi Å., Ackefors H., Lassig J., Leppäkoski E. (1981) Biological Oceanography. [In:] The Baltic Sea (ed. A. Voipio). Elsevier Scientific Publishing Company, Amsterdam, 219-274.

Huber M. (2015) Meretrix lyrata (G. B. Sowerby II, 1851) - MolluscaBase, World Register of Marine Species. (Website: accessed 23th June, 2016, http://www.marinespecies.org/aphia.php?p $=$ taxdetails\&id=507776).
Ishikawa M., Kase T. (2007) Multiple predatory drill holes in Cardiolucina (Bivalvia: Lucinidae): Effect of conchiolin sheets in predation. Palaeogeography, Palaeoclimatology, Palaeoecology 254, 508-522.

Jackson D.J., McDougall C., Woodcroft B., Moase P., Rose R.A., Kube M., Reinhardt R., Rokhsar D.S., Montagnani C., Joubert C., Piquemal D., Degnan B.M. (2010) Parallel evolution of nacre building gene sets in molluscs. Molecular Biology and Evolution 27, 591-608.

Jura C. (2005) Gromada: małże - Bivalvia. [In:] Bezkręgowce - Podstawy morfologii funkcjonalnej, systematyki i filogenezy (ed. C. Jura). Wydawnictwo Naukowe PWN, Warszawa, 673-686.

Katti K.S., Katti D.R., Mohanty B. (2010) Biomimetic Lessons Learnt from Nacre. [In:] Biomimetics Learning from Nature (ed. A. Mukherjee). InTech Rijeka, Rijeka, 193-216.

Kosnik M.A., Alroy J., Behrensmeyer A.K., Fürsich F.T., Gastaldo R.A., Kidwell S.M., Kowalewski M., Plotnick, R.M, Rogers R.R., Wagner P.J. (2011) Changes in shell durability of common marine taxa through the Phanerozoic: evidence for biological rather than taphonomic drivers. Paleobiology, 37 (2), 303-331.

Lewandowski K. (2004) Biuletyn Monitoringu Przyrody 1/2004(5). Główny Inspektoriat Ochrony Środowiska.

López S., Ferreira C.E., Coutinho R., Rilov G. (2010) Predator-prey interactions in a bioinvasion scenario: differential predation by native predators on two exotic rocky intertidal bivalves. Marine Ecology Progress Series, 403, 101-112.

Meyers M.A., Chen P.Y., Lopez M.I., Seki Y., Lin A.Y.M. (2011) Biological materials: A materials science approach. Journal of the Mechanical Behavior of Biomedical Materials, 4(5), 626-657. 
de Paula S. M., Silveira M. (2009) Studies on molluscan shells: Contributions from microscopic and analytical methods. Micron, 40, 669-690.

Piechocki A. (2009) Gromada: Małże Bivalvia. [In:] Zoologia - Bezkręgowce Tom I (ed. C. Błaszak). Wydawnictwo Naukowe PWN, Warszawa, 508-552.

Pokryszko B. (2009) Podtyp: Muszlowce Conchifera. [In:] Zoologia - Bezkręgowce Tom I (ed. C. Błaszak). Wydawnictwo Naukowe PWN, Warszawa, 425-426.

Poorten J., Gofas S. (2014) Cerastoderma edule (Linnaeus, 1758) - MolluscaBase, World Register of Marine Species. (Website: accessed 23th June, 2016, http://www.marinespecies.org/aphia.php?p $=$ taxdetails\&id=138998).

Ragaini L., Di Celma C. (2009) Shell structure, taphonomy and mode of life of a Pleistocene ostreid from Ecuador. Bollettino della Società Paleontologica Italiana, 48 (2), 79-87.

Salinas C., Kisailus D. (2013) Fracture Mitigation Strategies in Gastropod Shells. The Journal of The Minerals, Metals \& Materials Society (TMS) 65, 474-480.

Sarikaya M., Gunnison K.E., Yasrebi M., Aksay I.A. (1989) Mechanical PropertyMicrostructural Relationships in Abalone Shell. Materials Research Society Symposium Proceedings 174, 109-116, DOI:10.1557/PROC-174-109

Taylor J.D., Layman M. (1972) The mechanical properties of Bivalve (Mollusca) shell structure. Palaeonthogy 15(1), 73-87.
Thompson R.J. (1979) Fecundity and reproductive effort in the blue mussel (Mytilus edulis), the sea urchin (Strongylocentrotus droebachiensis), and the snow crab (Chionoecetes opilio) from populations in Nova Scotia and Newfoundland. Journal of the Fisheries Research Board of Canada 36(8), 955-964, DOI: $10.1139 / 779-133$

Urbański J. (1989) Gromada: Bivalvia (Lamellibranchiata, Acephala, Pelecypoda) - małże (blaszkoskrzelne). [In:] Zoologia Bezkręgowce Tom I Część trzecia (ed. E. Grabda). Wydawnictwo Naukowe PWN, Warszawa, 805-851.

Vendrasco M.J., Porter S.M., Kouchinsky A.V., Li G., Fernandez C.Z. (2010) Shell microstructures in early Mollusks. The Festivus XLII(4), 43-54.

Vermeij G.J. (1977) The Mesozoic marine revolution: Evidence from snails, predators and grazers. Paleobiology 3, 245-258.

Vermeij G.J. (1987) Evolution and Escalation. An Ecological History of Life. Princeton University Press.

Vincent J.F.V., Bogatyreva O.A., Bogatyrev N.R., Bowyer A., Pahl A.K. (2006) Biomimetics - its practice and theory. Journal of The Royal Society Interface 3, 471-482.

Zuschin M., Stanton Jr.R.J. (2001) Experimental Measurement of Shell Strength and Its Taphonomic Interpretation. PALAIOS, 16(2), 161-170. 